\title{
Trade and Labor Standards
}

\author{
DRUSILLA K. BROWN \\ Department of Economics, Tufts University, Medford, MA 02155
}

ALAN V. DEARDORFF

School of Public Policy, University of Michigan, Ann Arbor, MI 48109-1220

ROBERT M. STERN

School of Public Policy, University of Michigan, Ann Arbor, MI 48109-1220

rmstern@umich.edu

\section{Key words:}

J EL Classification Number: F1, F13

\begin{abstract}
The purpose of our paper is to explore the different views of the issues of international labor standards and to explore the available options for addressing these issues. We conclude that: (1) there is no convincing case on theoretical or empirical grounds for incorporating labor standards into the WTO and into U.S. trade agreements; (2) the surest way to improve labor standards is for the United States and other industrialized countries to maintain open markets and to encourage the economic growth of their developing country trading partners; and (3) steps should be taken to support the activities of the International Labour Organization (ILO) to provide inducements and technical assistance to help developing countries raise their labor standards.
\end{abstract}

\section{Introduction}

The interaction of labor standards and international trade policy is by no means a new issue. Nonetheless it has assumed new importance due to the increasingly vocal arguments by labor interests and social activists in the United States that issues of "unfair" labor practices and conditions have been ignored in both U.S. trade policies and in multilateral trade negotiations and therefore should be placed high on the U.S. national and multilateral trade policy agenda. Issues of lax enforcement of labor standards in Mexico were at the center of the public debate in the United States especially in 1992-93 when the North American Free Trade Agreement (NAFTA) was being negotiated and later submitted for approval by the U.S. Congress. Efforts were also made (unsuccessfully) at the December 1996 World Trade Organization (WTO) Ministerial Meeting in Singapore to extend the WTO to include rules governing trade-related labor standards. Labor standards were again at issue in the fast-track authority that the Clinton Administration requested from Congress in November 1997 and then withdrew because of insufficient support from House Democrats. 
The concern of labor and social activists is that the increased imports from countries in which labor standards are ostensibly not enforced at a sufficiently high level will be detrimental to wages and working conditions in the United States and other industrialized countries. As we will note in our discussion that follows, there is a wide disparity of views on issues of international labor standards. The purpose of this paper is to explore these different views and the available options for addressing the issues involved. We conclude that: (1) there is no convincing case for incorporating labor standards into the WTO and into U.S. trade agreements; (2) the surest way to improve labor standards is for the United States and other industrialized countries to maintain open markets and to encourage the growth of their developing country trading partners; and (3) steps should be taken to support the activities of the International Labour Organization (ILO) to provide inducements and technical assistance to help developing countries raise their labor standards.

The paper is structured as follows. Section 2 deals with the definition and scope of labor standards. Theoretical aspects of the economic effects of labor standards are considered in Section 3, while Section 4 summarizes the available empirical evidence. The monitoring and enforcement of labor standards are discussed in Section 5. Conclusions and implications for policy are presented in Section 6.

\section{Definition and scope of labor standards}

Labor standards are multi-faceted and may vary from country to country depending on the stage of development, per capita income, and political, social, and cultural conditions and institutions. It may be difficult therefore to distinguish unambiguously those labor standards that everyone would consider to be universal human rights from other labor standards that will depend on given national circumstances. Nonetheless, efforts have been made to identify and achieve consensus on a group of so-called core labor standards which ideally should apply universally. For example, according to OECD (1996, p. 26), core labor standards include: (1) prohibition of forced labor; (2) freedom of association; (3) the right to organize and bargain collectively; (4) elimination of child labor exploitation; and (5) nondiscrimination in employment.

Agreement on the universality of these core labor standards derives from the widespread acceptance and ratification of United Nations Covenants and Conventions as well as acceptance (though not necessarily ratification) of the pertinent Conventions of the ILO that deal with human rights and labor standards. ${ }^{1}$ Besides the aforementioned core standards, there are other labor standards that are less universally accepted, and that relate to "acceptable conditions of work," which include: a minimum wage; limitations on hours of work; and occupational safety and health in the workplace. ${ }^{2}$

To illustrate some of the difficulties that may arise in interpreting and implementing core standards and distinguishing between core and other standards, it is interesting to note what Fields $(1995$, p. 13) has proposed as "...a set of 
basic labour rights for workers throughout the world:

(i) No person has the right to enslave another or to cause another to enter into indentured servitude, and every person has the right to freedom from such conditions.

(ii) No person has the right to expose another to unsafe or unhealthy working conditions without the fullest possible information.

(iii) Children have the right not to work long hours whenever their families' financial circumstances allow.

(iv) Every person has the right to freedom of association in the workplace and the right to organise and bargain collectively with employers."

To illustrate further, Aggarwal (1995, pp. 4-5) has proposed that a distinction be drawn between standards related to labor processes and standards related to labor outcomes. This distinction would apply some definition of what constitutes a "minimum" standard to the determination of basic worker rights in terms of labor processes. Presumably, the point of taking labor processes, rather than outcomes, into account is to make allowance for differences and changes over time in the level of economic development and related factors. What remains unclear, however, as Aggarwal acknowledges, is the difficulty of deciding whether the identification and guarantee of labor processes provide an effective pre-condition for attaining the minimum criteria associated with achieving labor outcomes.

While, as already mentioned, there is concern in the United States that many of its developing country trading partners appear to be violating certain basic worker rights, ${ }^{3}$ it has been pointed out, for example, by B hag wati (1995, pp. 754$55 ; 1997)$ that the United States is itself open to criticism when it comes to the realization of several labor standards. He argues accordingly that it is "morally obtuse" for the United States to seek to impose on poor countries particular requirements relating to worker rights, while not extending these efforts to its own problems in the proposed international standards. ${ }^{4}$

The foregoing discussion is by no means intended to deny the desirability of improving working conditions through higher labor standards. The issue, rather, is how this can best be accomplished. We shall have more to say on this below in discussing existing institutions and mechanisms for the monitoring and enforcement of labor standards. It may be useful first though to discuss the central theoretical issues and the available empirical evidence involved in analyzing the economic effects of labor standards.

\section{Economic effects of labor standards: Theoretical considerations}

In this section, we consider two main issues: (1) the diversity of labor standards and the case for free trade; and (2) the effects of standards and the international harmonization of standards on economic welfare and the terms of trade of individual nations. 


\section{Diversity of standards and the case for free trade}

As noted in the preceding discussion, labor standards may vary across nations depending on their level of development, per capita incomes, and a host of political, social, and cultural conditions and institutions. The issue is whether such diversity of standards alters the case for free trade. This has been investigated in depth by Srinivasan $(1995,1997)$, based on a theoretical model in which standards use productive resources and also affect consumer welfare. The upshot of Srinivasan's theoretical analysis is that the diversity of labor standards between nations will reflect differences in factor endowments and levels of income, and that such diversity is consistent with the case for free trade. If minimum international labor standards are to be attained, it will be necessary to have arrangements for international income transfers and domestic tax/subsidies. This will be the case as well when consumers in countries with high standards have a moral preference to raise standards in their trading-partner countries. Further, if there are market failures that prevent the attainment of minimum labor standards, income transfers and domestic tax/subsidies will be required to achieve optimal conditions for resource allocation and consumer welfare. ${ }^{5}$ Finally, the use of trade intervention could hinder the attainment of higher labor standards, and it may be in the collective interests of countries to cooperate in setting labor standards. We shall have occasion below to examine the implications of Srinivasan's conclusions in considering the different options for dealing with international differences in labor standards.

\section{International harmonization of standards}

Brown, Deardorff, and Stern (BDS) (1996) analyze the effects of standards on economic welfare and the terms of trade and do not concern themselves directly with issues of the diversity of standards and the case for free trade. They employ a variety of theoretical models in which different national characteristics may determine the outcome of the introduction of labor standards. ${ }^{6}$

A general conclusion emerging from the BDS analysis is that economic welfare is best served when countries act to correct their domestic (labor) market failures. But, since these market failures will likely differ between countries, there is no obvious case on welfare grounds for pursuing universal standards and the international harmonization of standards that this may imply. This conclusion is consistent with that of Srinivasan, namely that diversity of working conditions between nations is the norm and is by no means in itself "unfair" so long as the extant labor standards are consistent with efficient resource use. ${ }^{7}$ Further, despite the good intentions of government, it may well turn out that the imposition of labor standards may fail to correct a market failure if the preferences of workers are heterogeneous with respect to what they consider to be acceptable levels of, say, health and safety conditions in the workplace. ${ }^{8}$

In considering the economic consequences that may result from pursuing the international harmonization of labor standards, BDS conclude that in cases 
in which low-income countries are relatively labor abundant, harmonization of child labor and certain other standards will reduce the effective labor endowment of these countries and thereby the supply of labor-intensive production on the world market. This could improve (worsen) the terms of trade of the low (high) income countries, although this is not what the high-income countries may intend.

BDS further assess arguments for having standards imposed on low-income countries. They note that low-income countries might benefit in case a government is unable for domestic political reasons to enact legislation on its own, although this presumes that the policy in question will indeed correct a market failure. Another possibility is that requiring the guarantee of such standards as the right of workers to organize may serve to reinforce development of democratic institutions. Finally, they ask if there is any justification for high-income countries to take countervailing actions against the ostensibly unfair labor standards of their trading partners. They answer in the negative so long as resources are being employed efficiently. If, nonetheless, a high-income country imposes a tariff or quota on labor-intensive imports from a low-income country, this will obviously be harmful to the economic interests of workers in the low-income country. In general then, the case for international harmonization of labor standards appears rather weak, and it is quite possible that harmonization could have unintended adverse consequences for the very people they are intended to protect. Based on the BDS analysis, it is difficult therefore to generate much theoretical support for pursuit of core labor standards that would have universal application.

\section{Labor standards as private/public goods}

We have already indicated that there may be a strong moral basis motivating the pursuit of higher labor standards. ${ }^{9}$ Thus, in his analysis noted above, Srinivasan made allowance for moral considerations so that consumers could express their concern by a willingness to pay relatively higher prices for goods and services that reflected higher labor standards. In this connection, there is an issue of whether labor standards are to be considered as public or private goods. As long as the same standards appear in the utility functions of more than one individual, the standards are public goods. Suppose, on the other hand, that individual consumers have a sense of virtuousness and derive pleasure from believing that the good they are consuming embodies some acceptably high level of labor standards. In this case, individual consumers care only about their own satisfaction and not about others, so that labor standards can be treated as private goods.

This view of higher standards as private goods has been expressed most forcefully by Freeman (1994a), who argues that a market solution based on labeling may be an especially effective way to raise labor standards internationally. He makes the point that labeling has the advantage that consumers pay more for what they consider morally acceptable, and at the same time foreign 
suppliers are compensated for their increased costs. Labeling also undercuts protectionist influences. ${ }^{10}$

It is not altogether clear, however, that labor standards should be considered to be private goods that lend themselves to a market-based treatment dependent on supplying all relevant information to consumers. If instead, labor standards take the form of public goods, Freeman (p. 30) acknowledges that some type of government intervention may be called for. ${ }^{11}$ In their theoretical analyses, Srinivasan and Brown, Deardorff and Stern considered cases of domestic market failure in which a governmentally imposed tax/subsidy arrangement would be introduced to correct the distortion and permit the first-best optimum to be attained. While tax/subsidy (price-based) arrangements have a clear theoretical appeal, it is important to recognize in dealing with issues of labor standards that governments often prefer to use nonprice measures, i.e., legal regulation and enforcement. ${ }^{12}$ Freeman (p. 29) cites a number of regulatory examples in U.S. law, including prohibition of slavery, restrictions on child labor, occupational health and safety standards, and discrimination in the workplace. As he argues, the choice of different policy measures will depend on given empirical and institutional circumstances, and it is likely that some combination of price-based and regulatory approaches will produce the best results.

\section{Political economy aspects of international labor standards}

In discussing the sources of support for governmental action on labor standards, it is important to identify the constituent interest groups involved. Thus, it would appear that in the United States organized labor, import-competing firms, and human-rights and public-interest groups are the main proponents of stricter labor standards applied to low-income countries. These interest groups may often recommend policies, including sanctions and import restrictions, which are intended ostensibly to change the behavior of trading-partner governments. By the same token, interest groups are influential in many low-income countries, especially among unionized workers in manufacturing sectors, employees of state enterprises, and owners/managers of import-competing firms. These groups may seek to protect and enhance their own ends and to resist foreign intrusion in setting standards. Krueger (1997, p. 283) characterizes the protectionist motivation as the "prevailing political economy view of international labor standards." 13,14 The issue then is how governments choose to respond to the various interest groups.

\section{Economic effects of labor standards: Empirical evidence}

\section{Labor standards and trade}

In our earlier discussion, we distinguished "core" and "other" labor standards. The question then is the extent to which international differences in the various standards affect trade performance. 
Rodrik (1996) represents an especially noteworthy effort to determine whether labor standards matter for trade. Using a variety of measures of labor standards and factor endowments, based on information for the 1980s and 1990s Rodrik first investigated whether labor standards affect labor costs. Making allowance for the effects of worker productivity in a sample of 36 countries, he found that per capita income was strongly correlated with labor costs and hence higher labor standards. Turning next to the effects on trade, he found that only the factor endow ment (comparative advantage) variables were statistically significant and that none of the labor standard indicators were statistically significant.

Another study of interest is Aggarwal (1995), who investigated in detail the relationships of labor standards and the pattern of U.S. imports from ten major developing countries that accounted for 26.5 percent of U.S. imports in 1994. Aggarwal's major findings ( $p .7)$ were as follows:

"Sectors typically identified as having egregious labor conditions do not occupy the only or even the primary share of these countries' exports.

Comparisons across more export-oriented and less export-oriented sectors indicate that core labor standards are often lower in less export-oriented or non-traded sectors such as agriculture and services.

Similarly, within an export-oriented sector, labor conditions in firms more involved in exporting are either similar to or better than those in firms that are less involved in exporting.

Changes in technology and the structure of international trade are leading developing countries to compete in a race upward in terms of product quality rather than a race downward with respect to price.

...Wages and working conditions in developing countries have been exhibiting positive trends. In general, these have been in line with productivity changes." 15

Finally, we may cite some of the main conclusions from the OECD study of Trade, Employment and Labour Standards (1996, pp. 12-13):

"...empirical research suggests that there is no correlation at the aggregate level between real-wage growth and the degree of observance of freedomof-association rights;

...there is no evidence that low-standards' countries enjoy a better global export performance than high-standards countries;

.... detailed analysis of US imports of textile products (for which competition from low-standards countries is thought to be most intense) suggests that imports from high- standards' countries account for a large share of the US market. Moreover, on average, the price of US imports of textile products does not appear to be associated with the degree of enforcement of child labour standards in exporting countries...." 
While the studies cited above may not constitute the final word on the relationships between labor standards and trade, the conclusion seems inescapable that there is little compelling empirical evidence suggesting that low labor standards have an impact on trade. ${ }^{16}$

\section{Labor standards and foreign direct investment (FDI)}

It is often alleged that multinational enterprises may be attracted to locate in countries with lower labor standards to take advantage of lower costs. The available empirical evidence actually indicates the opposite to be the case.

Thus, Rodrik (1996) investigated the determinants of U.S. FDI abroad during 1982-89, including measures of foreign exchange distortions, population, and income growth in host countries together with the various indicators of labor standards. He found (p. 22) that countries that scored lower in guaranteeing civil liberties and political rights and that had difficulty in providing for and enforcing standards affecting child labor have received less foreign investment during 1982-89 than would have been predicted on the basis of other country characteristics. Taken at face value, he concluded that these results indicate that low labor standards may be a hindrance, rather than an attraction, for foreign investors. Aggarwal (1995, p. 7) reached a similar conclusion: "U.S. foreign direct investment is not typically concentrated in countries or industries with poor labor standards." Finally, as reported in $\operatorname{OECD~}(1996$, p. 13): “...while core labour standards may not be systematically absent from the location decisions of OECD investors in favour of non-OECD destinations, aggregate FDI data suggest that core labour standards are not important determinants in the majority of cases."

Thus, the empirical evid ence suggests rather convincingly that low labor standards are not reflected in the existing trade performance of the major developing countries and that FDI is more attracted to countries with high rather than low standards.

\section{Labor standards and the role of interest groups}

As mentioned above, there is a view that is widespread that support for international labor standards reflects protectionist interests in the United States and other industrialized countries. In an effort to test this proposition empirically, Krueger (1997) analyzed the determinants of support in the U.S. House of Representatives for the Child Labor Deterrence Act of 1995. If this type of legislation were approved, it could prohibit imports of goods produced abroad by child labor under specified circumstances, including by children under 15 years old and subject to a review of child labor practices by the U.S. Secretary of Labor. The Act was co-sponsored by Senator Tom Harkin (D-IA) and Congressman Barney Frank (D-MA), with 35 co-sponsors in the House and 7 in the Senate. Krueger (p. 289) found that “...Congressmen from districts with a high 
concentration of high school dropouts are less likely to co-sponsor the Child Labor Deterrence Act. ...This finding is contrary to what I would expect from a simple political economy model...." Krueger also found that higher rates of unionization were associated with support for the Act as were representatives who were Democrats and also had voted against NAFTA and GATT.

In interpreting his results, Krueger (p. 293) suggested that the demand for international child labor standards should be considered to be a "normal" good, following Freeman (1994a). That is, voters with higher socioeconomic attainment will select Congressmen who favor limitations on employment of child labor. He further argued that unionized workers who tend to be more highly skilled and thus may not benefit directly from a ban on imported goods made with child labor may in this case be acting to pursue policies that strengthen worker rights more generally rather than pursuing their own narrow self interest. He goes on more broadly to state (pp. 293-94): “Indeed, in many instances I am surprised that the AFL-CIO used its limited political capital to press for international labor standards that are of little benefit to its members, when instead it could pursue policies that are of much greater direct benefit to its membership." 17

While Krueger's results are suggestive, they are by no means definitive. In partic ular, as Srinivasan $(1996,1997)$ has noted, a representative may have chosen not to sponsor the legislation and yet may be supportive of it. Further, since less educated and less skilled individuals tend to vote less, their interests may not have been given sufficient weight in the representative's deciding whether or not to be a cosponsor. Finally, Krueger's results suggest support for the legislation from representatives from districts with a higher rate of unionization and voting records opposing NAFTA and GATT.

Another noteworthy empirical study is by Freeman (1993) who investigated the evidence in developing countries for and against government intervention designed to introduce/remove labor-market distortions and, alternatively, to enhance labor-market institutions. ${ }^{18}$ He labels these two views, respectively, the "World Bank Distortion View" and the "International Labour Organization (ILO) Institutional View." These views differ insofar as removing interventions is believed to enhance economic efficiency and welfare in the former, whereas in the latter introducing interventions is believed to lead to these same results. To investigate the validity of these alternative views, Freeman examined evidence on labor-market policies and institutions for selected developing countries mainly during the 1980s. His empirical findings suggest that neither the distortion nor the institutional view is clearly supported by the available data. In particular, real and relative wages in developing countries turned out to be much more flexible in response to changing market conditions than the strict distortionist view would suggest. ${ }^{19}$ Freeman's overall conclusion was that the costs and benefits of the labor-market policies that may be adopted will depend on individual country circumstances. ${ }^{20}$

This selective review of labor standards and the role of interest groups suggests some ambiguities with respect to the issues. While there may thus be 
scope for different views, in our judgment the weight of the theoretical and empirical analysis does not justify taking an activist position to mandate and enforce international labor standards. ${ }^{21}$ Nonetheless, because issues of labor standards will continue to have a high profile in the current policy environment, it is essential to consider the alternative arrangements that exist for their monitoring and enforcement. This will be done in the following section. We will conclude with some recommendations that may serve the interests and needs of the United States and other high-income countries as well as the low-income countries.

\section{Monitoring and enforcement of labor standards}

Labor standards are presently dealt with in a variety of settings: global; regional; national/unilateral; and other, including private, arrangements. We shall discuss briefly each of these in turn.

\section{Global arrangements}

The main international organization that is concerned with labor standards is the ILO, which was established as part of the Treaty of Versailles of 1919 following the end of World War I. The methods and principles set out in the ILO constitution deal with all conceivable aspects of labor standards. As stated in ILO (I988, p. 4), ILO action designed to promote and safeguard human rights takes three main forms: (1) definition of rights, especially through adoption of ILO Conventions and Recommendations; (2) measures to secure the realization of rights, especially by means of international monitoring and supervision but not by imposition of trade sanctions; and (3) assistance in implementing measures, particularly through technical cooperation and advisory services.

We have already mentioned what might be considered to be ILO core labor standards. It is interesting that formal ratification of ILO Conventions differs considerably among ILO members, apparently because particular Conventions may be at variance with national laws and institutional practices. Thus, for example, as Rodrik (1996, pp. 15-16) notes, the United States has ratified only 11 ILO Conventions in all, whereas several other industrialized and developing countries have ratified a significantly larger number. Ratification of ILO Conventions may therefore not be an accurate indicator of existing national regulations governing labor standards, and there are many cases in which ratified Conventions are in fact not enforced. ${ }^{22}$

It is interesting in this connection, as Charnovitz (1987, pp. 566-567) has noted, that issues of alleged unfair competition involving labor standards were addressed in Article 7 of Chapter II of the 1948 (still-born) (Havana) Charter of the International Trade Organization (ITO). Since the GATT was conceived with a more narrow mandate as compared to the ITO, it did not address labor 
standards, except in Article XX(e) that provides for prohibition of goods made with prison labor. Charnovitz (p. 574) notes further that as early as 1953 the United States proposed (unsuccessfully) adding a labor standards article to the GATT. This would have empowered GATT members to take measures against other countries under the provisions of GATT Article XXIII (Nullification and Impairment). The United States continued, again unsuccessfully, to push for negotiation of a GATT article on labor standards in both the Tokyo and Uruguay Rounds of Multilateral Trade Negotiations in the 1970s and 1980s. But the international community was put on notice in April 1994 at the Marrakesh signing of the Uruguay Round accords that the United States intended to pursue issues of labor standards in future multilateral negotiations.

In the interim, there have been efforts at drafting a so-called social clause dealing with core labor standards and including trade sanctions for noncompliance that might eventually be incorporated into the WTO. As noted in Aggarwal (1995, p. 38), in J une 1994, the ILO began a research program dealing with the integration of social welfare and trade policy. A central objective was to develop a stronger enforcement mechanism. The ILO Secretariat proposed that the ILO and WTO work jointly on the oversight of international core labor standards, with the ILO concentrating on international monitoring and the WTO responsible for enforcement by means of trade-related sanctions. But because of disagreements among the country representatives of the ILO Working Party on the Social Dimensions of the Liberalization of International Trade, it was decided in early 1995 to suspend further discussion of the use of trade sanctions for alleged noncompliance with core labor standards. Instead, as noted in OECD (1996, p. 7), the ILO has undertaken a program of research on the effects of trade liberalization on core standards and a review of ILO means of action for the promotion of standards.

The United States, with some support from France and southern European Union members, Canada, and J apan, nonetheless continued to pursue the issue of trade and labor standards in the context of the WTO, and there was a concerted effort to add the issue to the agenda for the WTO M inisterial Meeting held in Singapore in December 1996.

In considering whether or not the WTO is an appropriate forum for dealing with trade and alleged violations of core labor standards, it is pertinent to note the conclusion reached in the OECD Report on Trade, Employment and Labour Standards (1996, pp. 16-17):

"Existing WTO provisions have not been designed for promoting core standards. Some of the suggestions under discussion would imply a reinterpretation of WTO practices and procedures while others would require to a greater or lesser extent renegotiation and amendment of WTO articles. Extending the WTO's Trade Policy Review Mechanism procedure to include labour standards would fall into the former category while other proposals would fall into the latter. In all cases, a consensus among WTO Members on the appropriateness and effectiveness of using WTO procedures to promote core 
labor standards and on the institutional changes required would have to be reached. Such a consensus does not exist at present. However, while some countries continue to call for discussion of the issue in the WTO and others are opposed, this remains an issue for international consideration. The debate on this issue and on the associated conceptual and practical difficulties will continue." 23

Rodrik (1996) makes a case for using the Uruguay Round safeguard procedures for investigating complaints arising from imports from countries with unacceptable labor standards that may be disruptive to domestic producing interests. He stresses the need for including the views of consumers and public interest groups in the importing countries as well as the views of foreign producers. Srinivasan $(1996,1997)$ has pointed out an important problem with Rodrik's argument, namely that there are all kinds of government regulations, besides labor standards, that influence production costs (e.g., building codes and zoning laws). Thus, in principle, objections might arise concerning imports that may not conform to any one or more domestic regulations. Singling out labor standards is then not convincing. It is not obvious, moreover, that the safeguard procedures, which are designed to be temporary, can be implemented with the broad representation that Rodrik recommends. Finally, as Anderson (1996) has observed, the U.S. experiences with antidumping and countervailing duty procedures certainly suggest how diffic ult it may be to avoid the temporary safeguard procedures from being captured by producing interests.

It is also worth noting that Freeman (1994a, p. 32) is somewhat inclined to support the inclusion of labor standards in trade agreements:

"Unlike trade economists who view any interference with free trade as the work of the devil, I would be pragmatic in this area. ...If trade negotiations are the only way to raise forcefully the standards flag in an international setting, why not? If trade sanctions can improve labor standards, that benefit must be weighed against the cost of lost trade. If trade sanctions can overturn an evil dictatorial regime and save human lives, go for it. Perhaps the standards issue will induce international trading groups to consider innovative ways that international trade might be used to finance improvements in standards."

Krueger (1997, p. 288) has expressed a similar view:

"Labor standards strike me as a legitimate subject of bargaining in trade negotiations. Presumably, a well-intentioned government will not accept an agreement unless, in total, it is expected to make the country better off. ...Because the demand for labor standards tends to rise with national income, many countries will choose on their own to strengthen and enforce their standards following trade agreements." 
While the views expressed by Freeman and Krueger may be justified on pragmatic and political grounds, there are better and less costly ways to effect improvements in labor standards. There is also the further important question of whether and how labor standards should be dealt with in the WTO multilateral context. The welfare gains from trade liberalization have long been a central feature of nondiscrimination in the GATT system. It would be a major departure from precedent if countries with allegedly low labor standards were now to be denied improved market access on these grounds. ${ }^{24}$

The debate on whether labor standards should be placed under the WTO's purview was apparently resolved in the negative at the December 1996 WTO Ministerial Meeting. Thus, as reported by Williams in The Financial Times (December 16, 1996, p. 4):

"Predictably hardest to resolve was the issue of labour standards, where the U.S. threatened to veto the entire declaration if no mention was made. Ministers eventually agreed to uphold internationally recognised core labour standards,.... But trade sanctions to enforce them were rejected and there is no provision for follow-up work in the WTO, which is asked simply to maintain its (minimal) collaboration with the International Labour Organisation."

The U.S. position at the Singapore Ministerial Meeting could be interp reted in part as pre-election posturing by the Democrats especially since the Republicans have opposed linking labor standards and trade. Thus, the Republican controlled 104th Congress was reluctant to grant fast-track negotiating authority to the Clinton Administration so long as the intention was to include labor issues as part of any future trade negotiations. ${ }^{25}$ The Republican opposition was continued in the first session of the 105th Congress in 1997, and the Clinton Administration made an effort to mute its position on trade and labor standards in order to induce Republicans to approve fast-track negotiating authority. However organized labor, environmental interest groups, and human rights organizations mounted an intensive campaign to oppose fast track unless the legislation included explicit protection of labor rights and the environment. ${ }^{26}$ When it became clear in mid-November 1997 that there were insuffic ient Democratic votes to obtain fast-track approval in the House of Representatives, the legislation was withdrawn and presumably will be reintroduced in 1998. The link between trade and labor standards will therefore remain a highly visible and controversial issue of public discourse on future trade legislation.

Regional arrangements

European union. Issues of worker rights have been a focus of attention in the European Union (EU) because of concerns over low-wage competition from some EU member countries, persistent unemployment, and wage stagnation. 
Sapir (1995b) notes that the first efforts to address the harmonization of social policies in Europe can be traced back to early stages of European integration prior to 1958. According to De Boer and Winham (1993, p. 17), the issue of a Community-wide Social Charter was first broached in 1972. Subsequently, with the issuance in 1985 of the white paper signaling the intention to remove remaining barriers to trade and creation of a Single Market, a Community Charter of Fundamental Social Rights for Workers was drafted in 1988. This Charter, which is quite comprehensive and encompasses the "core" and "other" labor standards noted in our earlier discussion, ${ }^{27}$ was adopted by all EU members except the United Kingdom. It was hoped to incorporate the Social Charter into the Maastricht Treaty in December 1991, but this was opposed once again by Britain. The Social Charter was subsequently approved by the other $11 \mathrm{EU}$ members, but on a voluntary basis and not as part of the Maastricht Treaty. ${ }^{28}$

In his evaluation of the EU Social Charter, Sapir (1995a, pp. 742-743; 1996) concluded that harmonization of social policies was not a pre-condition of successful European trade liberalization and integration. He noted further that: "In the mid-1990s, differences in labour standards between member states remain substantial and 'social harmonisation' remains a distant reality. .... whatever harmonisation has been achieved in Europe, it could not have occurred without redistributive mechanisms between countries. In the absence of such mechanisms, the harmonisation of social policies cannot be contemplated internationally." 29

\section{NAFTA}

At the time that NAFTA was being negotiated, some observers urged that NAFTA include a Social Charter for North America as a possible means of protecting the interests of workers. ${ }^{30}$ Instead of including a Social Charter, however, and since the NAFTA had already been signed by the member countries in the summer of 1992, the newly elected Clinton Administration opted to pursue a separate side agreement covering labor issues as well as an agreement covering environmental issues. ${ }^{31}$ Aggarwal $(1995$, p. 34) has summarized the main features of the labor side agreement as follows:

"First, the NAFTA supplemental agreement contains a more comprehensive list of labor standards than the five typically present in U.S. trade programs [which are noted below]. The agreement commits each party to the promotion of eleven broad labor conditions ranging from freedom of association to migration policies. Second, the agreement does not attempt to apply U.S. standards or...common uniform criteria in its evaluation of labor conditions in other countries. Instead, the agreement contains different enforcement mechanisms for different standards. The complaint process consists of three stages-filing a petition with the domestic National Administrative Office (NAO), Ministerial consultations, and lastly consultation with the Evaluation 
Committee of Experts (ECE). Complaints pertaining to freedom of association, the right of collective bargaining, and/or the right to strike can only be taken to the second stage of the complaint process. More importantly, sanctions cannot be utilized to encourage enforcement of laws pertaining to these rights. Of the eleven labor principles, only the implementation of those pertaining to child labor, minimum employment standards, and occupational health and safety can be supported by sanctions." ${ }^{32}$

Because it required some time to establish the institutional framework following the implementation of NAFTA in J anuary 1994, there has been limited experience to date in administering the labor side agreement. As of November 1997, the U.S. NAO has received seven submissions alleging non-compliance by Mexico with its labor laws. These submissions have involved issues of freedom of association being denied to Mexican workers. No action was recommended on two submissions, the third was withdrawn, and the others are pending. Mexico has received one submission about U.S. noncompliance with its labor laws, involving closure of a subsidiary of the Sprint Corporation in San Francisco. This case is pending.

It is interesting to ask whether the NAFTA labor side ag reement might serve as a model for a global agreement that might in the future be incorporated into the WTO or into an expanded NAFTA. As far as a global agreement is concerned, the NAFTA side agreement goes beyond what are considered to be core labor standards and emphasizes the observance of existing national laws governing labor standards in the NAFTA member countries rather than the intercountry harmonization of these laws that proponents of labor standards favor. Further, not all standards are subject to sanctions and those that are (i.e., child labor, minimum employment standards, and occupational safety and health) are precisely ones that have engendered much of the ongoing controversy in the global context. Whether an agreement on labor rights and standards should be made a condition of expanding NAFTA to include Chile and other nations in the Western Hemisphere also appears problematic in our view on both conceptual and empirical grounds. We recognize of course that if future Congressional approval of fast-track negotiating authority is to be obtained, it almost certainly will have to acknowledge the importance of labor standards. But, in our view, the negotiating authority should stress the desirability of enhancing labor standards as an objective to be sought by sovereign nations and that trade sanctions not be used to impose labor standards on low income countries that may not be appropriate for their economic circumstances.

\section{National/unilateral arrangements}

As noted in Brown, Deardorff, and Stern (1996, p. 229), since the 1980s it has become increasingly common to include international labor standards criteria in U.S. foreign economic legislation. ${ }^{33}$ The most important of these actions 
have been in establishing eligibility for trade preferences in the 1983 Caribbean Basin Economic Recovery Act and the 1984 renewal of the Generalized System of P references (GSP), and making the foreign denial of worker rights actionable under Section 301 of the 1988 Trade Act. The 1988 Trade Act also expanded the requirements of the Departments of State and Labor to submit periodic reports to Congress on human rights abuses and foreign adherence to internationally recognized worker rights. The stipulations on labor standards in the GSP were made mandatory. GSP eligibility has in fact been revoked at times for a number of developing countries until they showed evidence that the offending actions had been or were in the process of being eliminated. Apparently prompted by the U.S. experience, the EU has adopted similar labor standards criteria for its GSP program to become effective in 1998.

While there may be instances in which countries have improved their labor standards in order to maintain GSP eligibility, these cases may not be important economically, considering the size of the countries involved and the limited benefits that the GSP offers because of the restricted product coverage. Also, in the future the value of GSP will be eroded as the result of implementing the tariff reductions negotiated in the Uruguay Round. Nonetheless, it may appear that the experiences with quid-pro-quo actions under the GSP program can possibly provide some useful insights into the design and implementation of policies and procedures governing trade-linked labor standards in other contexts. This may be misleading, however, since the removal of GSP eligibility is essentially decided unilaterally by the United States and the EU, both of which are obviously very powerful entities in the global trading system. ${ }^{34}$ Unilateral U.S. action can also be taken under Section 301 of the U.S. Trade Act. One should be wary therefore of arrangements in which developing countries may be coerced into taking actions detrimental to their own interests in response to pressures from their more powerful trading partners. ${ }^{35}$

\section{Other arrangements}

There are a number of other arrangements that deserve mention in addition to those already discussed above.

For example, as noted in OECD (1996, pp. 161-69), the OECD, ILO, UNICEF, and other UN agencies have been active in promoting cooperative programs of economic development in which practical measures backed up often by multilateral and bilateral financial assistance can be devised to deal with some of the underlying causes of poverty in poor countries that may be reflected in the employment of children and the absence or relatively weak enforcement of core labor standards. The OECD and ILO have also developed international codes of conduct applicable to multinational enterprises (M NEs) that may assist in improving labor standards and working conditions in MNE affiliates in host developing countries. Individual firms can attempt to develop codes of conduct on their own, as Aggarwal (1995, p. 39) has noted has been done by such 
U.S. MNEs as Levi Strauss, Liz Claiborne, Nike, Reebok, Sears, Timberland, and Walmart. These cooperative efforts and codes of conduct are essentially voluntary in nature, and, of course, there is no guarantee that they will be effective in all circumstances in low-income countries, as some firms have already discovered. Nonetheless, they serve an important role insofar as they help to focus attention on the importance of the root causes of underdevelopment and the types of business practices that may help low-income countries to raise per capita incomes and improve conditions of work.

Finally, we may reiterate the importance of consumer labeling in providing a market-based method for helping to improve labor standards when these standards can be treated as private goods. The advantage of labeling is that it provides information about production processes being used and allows consumers in making their consumption choices to reflect the satisfaction that they derive from the presumed realization of higher labor standards internationally. ${ }^{36}$ When labor standards are considered to be public goods, there will be a need for governmental policies. What is important is that these various private and public actions can be carried out without the coercion that may be involved when efforts are made internationally to influence governments to change their domestic labor-market policies. ${ }^{37}$

\section{Conclusions and implications for policy}

The motivation for this paper has been to consider whether international labor standards should be incorporated into the rules and mandate of the WTO which oversees the international trading system and into U.S. trade policies and trade agreements. A case could possibly be made for devising WTO rules and disciplines to improve core labor standards in low-income countries and, by the same token, to prevent the United States and other high-income countries from abusing their economic power in seeking measures that would be detrimental to the cost competitiveness and economic welfare of low- income countries. ${ }^{38}$ However, it is difficult in our view to make this case convincingly because of the diversity of labor standards in countries with differing national characteristics, policies, and institutions. Furthermore, our literature review suggests that there are no compelling theoretical and empirical grounds to support the international enforcement and harmonization of labor standards. ${ }^{39}$

What then should be done on the global level? Issues of international labor standards have historically been the province of the ILO, which is often criticized because it lacks a mechanism for enforcement of discipline to raise labor standards and because it espouses an interventionist social agenda. While these criticisms may be true, they miss the point in our judgment. There is ample evidence especially from the economies in East and Southeast Asia that labor standards and social conditions are improved as countries achieve higher levels of economic development and per capita incomes. If so, then what is needed are policies to provide technical and financial assistance to promote 
economic progress and the accompanying realization of higher labor standards in low-income countries.

With sufficient encouragement and increased financial support, the ILO can provide a multilateral forum that would serve to strengthen its role and authority in pursuing improved labor standards internationally. While the United States and many of the EU member countries wanted to link labor standards and trade in the December 1996 WTO M inisterial Meeting, we noted that their efforts were unsuccessful. The challenge then is to reinforce the institutional role for which the ILO has been designed. ${ }^{40}$

If the responsibility for monitoring and helping developing countries to improve their labor standards is centered in the ILO, there is no obvious case to be made for the United States to incorporate labor standards issues into its trade policies and trade agreements. We recognize that adherence to certain specified labor standards has been made a condition in U.S. preferential trade arrangements, especially in the GSP arrangements and in the labor side agreement in the NAFTA. There is not much evidence, however, that actual or threatened withdrawal of GSP has had much impact on developing country labor standards. Further, the actions initiated to date under the NAFTA labor side agreement have primarily involved alleged noncompliance with the right of freedom of association. Our review of the empirical evidence on labor standards and U.S. trade suggests that there is no case to be made that ostensibly low foreign labor standards are harmful to American firms and workers. Moreover, foreign direct investment appears to be more attracted to countries with high rather than low labor standards. Thus, as already stated, U.S. policies should be directed to maintaining open markets and encouraging the economic growth of its developing country trading partners. This is the surest way to achieve higher labor standards since there is pervasive evidence that standards are improved with higher levels of per capita incomes. U.S. policies in support of the activities of the ILO would also be helpful in providing inducements and technical and financial assistance to developing countries in raising their standards. ${ }^{41}$

\section{Acknowledgments}

We wish to thank J agdish Bhagwati and the anonymous referees for their helpful comments on an earlier version of our paper. The research underlying this paper was supported in part by a grant from the Ford Foundation to the School of Public Policy at the University of Michigan for a program of research and policy outreach on the role of interest groups in the design and implementation of U.S. trade policies.

\section{Notes}

1. According to OECD (1996, pp. 31-34), there are seven fundamental ILO Conventions that form the basis of consensus among the ILO's constituents. These include: prohibition of forced 
labour (No. 29); freedom of association and protection of the right to organize (No. 87); right to organize and collective bargaining (No. 98); equal remuneration for men and women for work of equal value (No. 100); abolition of forced labour (No. 105); nondiscrimination in employment and occupation (No. 111); and minimum age of employment of children (No. 138).

2. See Brown et al. (1996, Appendix Table 1) for the definitions and principles of the core and other labor standards that are articulated in U.S. trade law, based on Lyle (1991, pp. 20-31).

3. See, for example, Reich (1994).

4. A similar argument is made by Srinivasan $(1994,1995,1996,1997)$, who argues that humanitarian concerns need to be reflected in the willingness of citizens in developed countries to assume responsibility and pay financially to enhance the welfare of workers, including children, in developing countries.

5. Srinivasan points out that the case for promoting labor unions and collective bargaining, which is considered to be a core labor standard, is by no means obvious in many developing countries, especially where unions are concentrated in the organized manufacturing and public sectors rather than in agriculture where a relatively large proportion of the population may be employed.

6. See Bloom and Noor (1994) for research along related lines. Casella (1996) develops a model in which labor standards respond endogenously to changing levels of income. Further theoretical analysis of labor standards is to be found in Golub (1997), Maskus (1997), and OECD (1996, pp. 215-232).

7. An exception arises here in cases of slave labor and what may be considered to be egregious treatment of child labor.

8. See Maskus, Rutherford, and Selby (1996) for a computable general equilibrium (CGE) model analyzing the effects of changes in Mexico's labor standards. They demonstrate conditions in which improved labor standards may enhance the welfare of Mexican workers. See also Maskus (1997).

9. But it is important to be clear that concern about labor standards ought to be motivated by concern for the workers involved, and not for the workers with whom they compete. It is this latter view that motivates many of the advocates of labor standards. What these advocates may not realize or acknowledge is that taking actions against alleged violators of labor standards will normally make the "exploited" workers worse off, not better off. That will be true whether the sanctions are applied by government policy or by individual consumers responding to labeling. Therefore, if we wish to make workers and their families better off, we must find a way to raise their incomes, not take their incomes away.

10. However, as just noted, labeling does not in itself raise the incomes of foreign workers and their families.

11. Freeman's argument for consumer labeling may therefore be limited insofar as it rests on treating labor standards as private goods. He does not make clear, moreover, what role the government should play, if any, in providing information to consumers and facilitating labeling and preventing private labeling arrangements from being co-opted by producing interests.

12. It should be noted that this discussion refers to national or federal standards. J ohn H. J ackson has pointed out to us that there may be significant differences between U.S. states and regions in the impacts that national standards may have and yet the national standards remain operative. What helps this to work is that there is free movement of labor within the United States coupled with various programs of income support and transfers. As noted in the theoretical discussion above, one or both of these elements would be needed for an international system of labor standards to function effectively.

13. While Krueger's characterization may apply to unions and import-competing firms, it may not apply to the activities of human-rights and public-interest groups which are not motivated by protectionist considerations.

14. See Noor (1996) for development of a theoretical model in which labor standards may enhance protection in an industrialized country. Also, see T.N. Srinivasan's comment on Stern (1997). 
15. Aggarwal also had occasion to note that: the impact of imports from developing countries is small relative to imports from industrialized countries; countries with lower labor standards do not exhibit higher rates of import penetration than countries with relatively higher labor standards; and imports from developing countries do not appear to have larger displacement effects on U.S. employment and wages in sectors associated with poor labor standards relative to other sectors." See also Erickson and Mitchell (1996) who focus on the pattern and labor content of U.S. trade and find relatively small adverse wage effects and displacement of U.S. workers.

16. Alan Krueger has suggested to us that this is consistent with his view that the demand for international labor standards in the United States does not emanate from disguised protectionism. On this matter, however, see the discussion below of Krueger's research.

17. Krueger also examined other aspects of child labor, including the relationship between employment of children and GDP per capita and the experiences with compulsory schooling laws. He found that employment of young children was negatively related to GDP per capita. That is, child labor is more prevalent in low-income regions and negligible in high-income regions. This is a clear demonstration of the fact that restrictions on child labor can be looked at as a normal good, in this case less of it being condoned as per capita incomes rise. Evidence on the effects of compulsory schooling laws suggested that there may be definite benefits from such laws in high-income countries, but that there is widespread noncompliance with existing laws in many low-income countries. These findings suggest that reliance on child labor in low-income countries will diminish as family incomes rise, and that realization of the benefits of compulsory schooling laws depends on increasing economic opportunities and financial support for poor families so as to reduce their dependence on employment of their children.

18. See also Freeman (1994b) which contains empirical studies of labor-market institutions and policies in several industrialized countries and some lessons for the United States suggested by the experiences of other countries.

19. See Squire and Suthiwart-Narueput (1997) for data on real minimum wages for selected developing countries for 1970-1990 and for an analysis of how noncompliance with official minimum wages may reduce distortionary costs.

20. Linda Lim in commenting on Stern (1997) has pointed out that, in spite of the absence of formal worker rights and standards in such Southeast Asian countries as Malaysia, Singapore, and Indonesia, wages and working conditions have improved markedly. In contrast, the experiences in Thailand and the Philippines have been much less favorable even though these nations encouraged worker rights and minimum wages. She also noted that both Malaysia and Singapore have attracted considerable inflows of FDI and that workers have benefited in the firms involved. See also the comment by Mari Pangestu and evidence on Indonesian economic growth and accompanying improvement in social indicators noted in IMF (1997).

21. There is evidently a marked difference in world view between most advocates of labor standards and trade (and most other) economists. Labor advocates seem to see the world in terms of a struggle between capital and labor for the rewards from production, without much regard to the size of the output that they will have to share. They see the outcome as depending on power, not on economics. Trade economists see the world in terms of how resources are allocated to production with a view to maximizing the total output. They see the distribution of that output between capital and labor as depending on scarcity and productivity, not on power. Therefore labor advocates favor the use of intervention to tilt the balance of power in favor of labor, believing then that labor will get a larger share of a fixed pie. Trade economists see those same policies as shrinking the pie while altering the slices not by changing power but by changing the markets within which scarcity determines the rewards to capital and labor.

22. A detailed discussion of the observance of core labor standards in 75 selected countries is provided in OECD (1996, pp. 39-70).

23. John Martin has suggested to us that since the WTO has already been assigned a role in dealing with trade-related intellectual property rights (TRIPS) as a result of the Uruguay Round negotiations, it may be reasonable to include labor standards in the WTO as well. In our view, 
the inclusion of TRIPs in the WTO can be considered as an effort by the industrialized countries to capture the monopoly rents associated with intellectual property rights and thus ostensibly to prevent the "piracy" of these rights. This is a very different matter from dealing with intercountry differences in labor standards which may reflect variations in per capita income levels and a host of structural and institutional factors.

24. Our point therefore is not that we see the recommendations of Freeman and Krueger as "the work of the devil." Rather, we do not consider trade agreements and trade sanctions to be an effective and equitable means for raising international labor standards.

25. See, for example, U.S. House of Representatives (1995).

26. Thus, as reported by Greenhouse in The New York Times, February 20, 1997, p. C3: "Putting the labor movement on a potential collision course with President Clinton, AFL-CIO leaders voted “...to oppose extending the North American Free Trade Agreement to other countries unless it includes protections on labor and the environment that the Administration has previously rejected." This is a good example of the point we made earlier that advocates of labor standards apparently care more about protecting their own interests rather than the interests of supposedly exploited foreign workers.

27. The highlights of the Charter of Fundamental Social Rights are summarized in De Boer and Winham (1993, pp. 36-37), and the full text is to be found in Commission of the European Communities (1990).

28. It is interesting to note, with the advent of a Labor Government in the United Kingdom in the May 1, 1997 election, that B ritain has indicated that it will give its approval to the Social Charter and thus will no longer be the only EU member country not to accept the Charter.

29. For information on the degree of convergence (or lack of it) between the EU and the European Free Trade Area (EFTA) on labor standards, see the chapter on "Labour Standards and Economic Integration" in OECD (1994).

30. A useful reference is Lemco and Robson (1993).

31. At the time, the negotiation of these side agreements may have been helpful in obtaining Congressional approval of the NAFTA. However, as we note below, the resort to such side agreements does not carry over necessarily to other regional or multilateral trade agreements.

32. See also OECD (1996, pp. 178-183).

33. The standards include: (1) freedom of association; (2) the right to organize and bargain collectively; (3) freedom from forced labor; (4) a minimum age for employment; and (5) acceptable conditions of work, including a minimum wage, limitations on hours of work, and occupational safety and health rights in the workplace.

34. Further discussion of labor standards and trade preferences can be found in OECD (1996, pp. 182-190).

35. Srinivasan (1997) characterizes the GSP as "crumbs from the rich man's table which the developing countries should do well without."

36. Aggarwal (1995, pp. 39-40) cites the example of the Child Labor Coalition, which was formed in 1989 by several religious, human rights, and union groups for the purpose of informing consumers in high-income countries about child labor conditions used in producing goods such as rugs in South Asia. The Coalition has sponsored the so-called Rugmark campaign which provides producers with a certifying label that they can attach to their exports indicating that they do not employ child labor. According to de J onquieres and Williams (1996), the United States has proposed in the ILO that the Rugmark labeling system be extended to clothing and other products. See also U.S. Department of Labor (1996) for a report on codes of conduct for the U.S. apparel industry based on a survey of 42 companies and visits to six countries that are major apparel exporters to the U.S. market. These voluntary codes of conduct in the apparel industry have become increasingly common since the early 1990s, although monitoring and enforcement of the codes often present difficulties in many instances. The most recent example is the U.S. Presidential task force agreement to "end" apparel sweatshops worldwide and give a seal of approval to companies that comply with the code of conduct. For details, see Greenhouse in The New York Times, April 9, 1997, p. A11. 
37. But again note that worker and family incomes may not be raised if their effective labor supply is reduced by the various private/public actions.

38. Bernard Hoekman has suggested to us that some existing features in the WTO such as the agreements on pre-shipment inspection and trade-related intellectual property rights could be helpful in facilitating the provision of information to international traders and consumers.

39. We would take issue therefore with the point made in the OECD Report (1996, p. 14) that: "Even though efforts to improve observance of core labour standards may be facilitated by economic growth and freer trade, there are reasons to doubt that market forces alone will automatically improve the standards. Hence, the importance of more direct promotion mechanisms." The key words here are "automatically" and "direct." As we have tried to make clear in our discussion and as Srinivasan also notes in his comment on Stern (1997), it may well be that labor-market failures are present in many countries. But if this is the case, the optimal policies are domestic in character, and it is by no means obvious why international policies are preferred and how they can better overcome the domestic market failures at issue.

40. In considering the spectrum of international organizations that have been created over the years, Srinivasan $(1995,1997)$ points out that these organizations have been specialized according to function. For example, he notes the particular rules and mandates that apply to such organizations as the: ILO; GATT/WTO; UNCTAD; World Bank; International Monetary Fund; Universal Postal Union; and Berne and Paris conventions. The issue then is whether it is desirable and efficient to require that individual organizations assume responsibilities for rules for which the organizations were not designed. More specifically, he argues that issues of labor standards are best left to the ILO and should not be mandated to the GATT/WTO, which has been designed to articulate, monitor, and enforce the rules governing the international trading system. For similar views, see B hagwati (1995), Charnovitz (1995), and Pangestu (1996).

Some observers might take issue with the above characterization of the GATT/WTO, arguing that it constitutes a forum for discussion and negotiation on trade-related matters, and, in this light, should include issues of labor standards. But even if this were the case, there is a genuine possibility that the WTO could become overloaded if it were to take on labor standards as well as other new issues like the environment and competition policy.

41. See Charnovitz (1995) for suggestions for reinvigorating the ILO and for changes especially in U.S. policies that would serve to strengthen the ILO.

\section{References}

Aggarwal, Mita (1995) “International Trade, Labor Standards, and Labor Market Conditions: An Evaluation of the Linkages." USITC, Office of Economics Working Paper No. 95-06-C (J une).

Anderson, Kym (1996) "Social Policy Dimensions of Economic Integration: Environmental and Labour Standards." In T. Ito and A.O. Krueger (eds.) Regionalism vs. Multilateral Trade Agreements. Chicago: University of Chicago Press for the NBER.

Bhagwati, J agdish (1995) "Trade Liberalisation and 'Fair Trade' Demands: Addressing the Environmental and Labour Standards Issues," The World Economy 18, 745-759.

Bhagwati, J agdish (1997) "Fast Track: Not So Fast," Wall Street J ournal (September 10).

Bloom, David E. and Waseem Noor (1994) "Labor Standards and the Emerging World Economy," processed, Columbia University.

B rown, Drusilla K., Alan V. Deardorff, and Robert M. Stern (1996) "International Labor Standards and Trade: A Theoretical Analysis." In J agdish N. B hagwati, and Robert E. Hudec (eds.) Harmonization and Fair Trade: Prerequisites for Free Trade? Cambridge: MIT Press.

Casella, Alessandra (1996) "On Standards and Trade: A Review of Simple Results." In J agdish Bhagwati and Robert Hudec (eds.) Fair Trade and Harmonization: Prerequisites for Free Trade? Cambridge: MIT Press.

Charnovitz, Steve (1986) "The Influence of International Labor Standards on the World Trading Regime: A Historical Review," International Labour Review 126, 565-584. 
Charnovitz, Steve (1995) "Promoting Higher Labor Standards," The Washington Quarterly 18, 167190.

Commission of the European Communities (1990) The Community Charter of Fundamental Social Rights for Workers. European File 6/90. Brussels: Commission of the European Communities.

De Boer, Elizabeth and Gilbert R. Winham (1993) "Trade Negotiations, Social Charters, and the NAFTA," In J onathan Lemco and William B.P. Robson (eds.) Ties Beyond Trade: Labor and Environmental Issues under the NAFTA. Canadian-American Committee: C.D. Howe Institute (Canada) and National Planning Association (U.S.A.).

Erickson, Christopher L. and Daniel J .B. Mitchell (1996) "Labor Standards and International Trade: Background Analysis," presented at conference on "The Multilateral Trading System in a Globalizing World," sponsored by the East-West Center (August 7-9).

Fields, Gary (1995) Trade and Labour Standards: A Review of the Issues. Paris: OECD.

Freeman, Richard B (1993) "Labor Market Institutions and Policies: Help or Hindrance to Economic Development?" Proceedings of the World Bank Annual Conference on Development Economics 1993, pp. 117-144.

Freeman, Richard B (1994a) "A Hard-Headed Look at Labor Standards," in U.S. Department of Labor, Bureau of International Labor Affairs, International Labor Standards and Global Economic Integration: Proceedings of a Symposium. Washington, D.C.: U.S. Department of Labor.

Freeman, Richard B (1994b) "Lessons for the United States." In Richard B. Freeman (ed.) Working Under Different Rules. New York: Russell Sage Foundation.

Golub, Stephen S (1997) "International Labor Standards and International Trade." Paper prepared for the International Monetary Fund (J anuary).

Greenhouse, Steven (1997a) "Apparel Industry Group Moves to End Sweatshops," The New York Times, April 9, 1997, p. Al1.

Greenhouse, Steven (1997b) "Union Leaders Oppose Expanding Free-Trade Treaty Without Modifications," The New York Times, February 20, p. C3.

International Labour Organization (ILO) (1988) "Human Rights: A Common Responsibility," International Labour Conference, 75th Session, 1988. Geneva: ILO.

International Monetary Fund (1997) “Indonesian Economic Growth Accompanied by Improved Social Indicators," IMF Survey (August 18).

Krueger, Alan (1997) "International Labor Standards and Trade," Annual World Bank Conference on Development Economics 1996. Washington, D.C.: The World Bank, 281-302.

Lemco, J onathan and William B.P. Robson (eds.) (1993) Ties Beyond Trade: Labor and Environmental Issues under the NAFTA. Canadian-American Committee: C.D. Howe Institute (Canada) and National Planning Association (U.S.A.).

Lyle, Faye (1991) "Worker Rights in U.S. Policy," Foreign Labor Trends, 91-54, U.S. Department of Labor, Bureau of International Labor Affairs. Washington, D.C.: U.S. Government Printing Office.

Maskus, Keith E (1997) “Should Core Labor Standards Be Imposed Through International Trade Policy?" Policy Research Working Paper, WPS 1817, The World Bank Development Research Group (August).

Maskus, Keith E., Thomas J . Rutherford, and Steven Selby (1996) "Implications of Changes in Labor Standards: A Computational Analysis for Mexico," North American J ournal of Economics and Finance 6, 171-188.

Noor, Waseem (1996) “Labor Standards: A Guise for Protectionist Policy?" Processed, Columbia University.

Organization for Economic Cooperation and Development (OECD) (1994) OECD Employment Outlook. Paris: OECD.

Organization for Economic Cooperation and Development (OECD) (1996) Trade, Employment and Labour Standards: A Study of Core Workers Rights and International Trade. Paris: OECD.

Pangestu, Mari (1996) "Asia to West: Stop Playing the Labor Game," The Asian Wall Street J ournal Weekly () uly 1) p. 18. 
Reich, Robert (1994) "Keynote Address," in U.S. Department of Labor, Bureau of International Labor Affairs, International Labor Standards and Global Economic Integration: Proceedings of a Symposium. Washington, D.C.: U.S. Department of Labor.

Rodrik, Dani (1996) "Labor Standards in International Trade: Do They Matter and What Do We Do About Them?" In Robert Lawrence, Dani Rodrik, and J ohn Whalley (eds.) Emerging Agenda for Global Trade: High Stakes for Developing Countries. Washington, D.C.: Overseas Development Council.

Sapir, André (1995a) "Symposium: Does Free Trade Require Fair Trade and Harmonisation? Introduction," The World Economy 18, 741-744.

Sapir, André (1995b) "The Interaction Between Labour Standards and International Trade Policy," The World Economy 18, 791-803.

Sapir, André (1996) "Trade Liberalization and the Harmonization of Social Policies: Lessons from European Integration." In J agdish N. Bhagwati and Robert E. Hudec (eds.) Fair Trade and Harmonization: Prerequisites for Free Trade? Cambridge: MIT Press.

Squire, Lyn and Sethaput Suthiwart-Narueput (1997) "The Impact of Labor Market Regulations," World Bank Economic Review 11, 119-143.

Srinivasan, T.N. (1994) "International Labor Standards Once Again." In U.S. Department of Labor, Bureau of International Labor Affairs, International Labor Standards and Global Economic Integration: Proceedings of a Symposium. Washington, D.C.: U.S. Department of Labor.

Srinivasan, T.N. (1995) "International Trade and Labour Standards." In Pitou van Dijck and Gerrit Faber (eds.), Challenges to the New World Trade Organization. Amsterdam: Martinus Nijhoff/Kluwer.

Srinivasan, T.N. (1996) "Post-Uruguay Round Issues for Asian Member Countries," Asian Development Review 14, 1-43.

Srinivasan, T.N. (1997) "Trade and Human Rights." In Alan V. Deardorff and Robert M. Stern (eds.) Representation of Constituent Interests in the Design and Implementation of U.S. Trade Policies. Ann Arbor: University of Michigan Press, forthcoming.

Stern, Robert M. (1997) "Issues of Trade and International Labor Standards in the WTO System," The Emerging WTO System and Perspectives from East Asia, J oint U.S.-Korea Academic Studies, vol. 7. Washington, D.C.: Korea Economic Institute of America. With comments by T.N. Srinivasan, Linda Lim, and Mari Pangestu.

U.S. Department of Labor, Bureau of International Labor Affairs (1996) The Apparel Industry and Codes of Conduct: A Solution to the International Child Labor Problem. Washington, D.C.: U.S. Department of Labor.

U.S. House of Representatives, One Hundred Fourth Congress, First Session, J oint Hearing Before the Subcommittee on Trade of the Committee on Ways and Means and the Subcommittee on Rules and Organization of the House of the Committee on Rules (1995) Fast Track Issues. Washington, D.C.: U.S. Government Printing Office (May 11 and 17).

Williams, Frances (1996) "Singapore Deals Give a Boost to WTO," The Financial Times (December 16), p. 8. 